\title{
Lipid requirement using different oil sources in Mayan cichlid Cichlasoma urophthalmus larvae (Percoidei: Cichlidae)
}

\author{
Daniel Calzada-Ruiz ${ }^{1}$, Carlos Alfonso Álvarez-González ${ }^{1}$, Emyr Peña $^{1,3}$ \\ Luis Daniel Jiménez-Martínez ${ }^{1}$, Juan Pablo Alcantar-Vázquez ${ }^{2}$, Felipe Becerril-Morales ${ }^{2}$ \\ Rafael Martínez-García ${ }^{1}$ \& Susana Camarillo-Coop ${ }^{1}$ \\ ${ }^{1}$ Laboratorio de Acuicultura Tropical, División Académica de Ciencias Biológicas \\ Universidad Juárez Autónoma de Tabasco, Tabasco, México \\ ${ }^{2}$ Laboratorio de Acuicultura, Universidad del Papaloapan, Loma Bonita, Oaxaca, México \\ ${ }^{3}$ Consejo Nacional de Ciencia y Tecnología, Ciudad de México, México \\ Corresponding author: Carlos Alfonso Álvarez-González (alvarez_alfonso@hotmail.com)
}

\begin{abstract}
The effect of different lipid levels (10, 15, 20 and 25\%) and oil sources (fish oil: FO and soybean lecithin oil: LO) on growth, survival, digestive enzymatic activity, gene expression acetyl CoA carboxylase (ACC1) and fatty acid synthase (FAS) of Mayan cichlid larvae Cichlasoma urophthalmus were evaluated by a bi-factorial design. The larvae were fed from hatching with eight different experimental isoproteic diets (45\% protein) and a commercial diet for tilapia as a control diet. The results showed that larvae fed the LO15 diet had the highest growth in weight and total length and higher trypsin activity. The lowest values in FAS and ACC1 expression were obtained exclusively with the lipid type (soybean lecithin). It is concluded that the inclusion of soybean lecithin at a concentration of $15 \%$ allows the $100 \%$ replacement of fish oil in balanced feed for the culture of Mayan cichlid larvae.
\end{abstract}

Keyword: acetyl CoA carboxylase; fatty acid synthase; lecithin lipase; lipogenesis; aquaculture

\section{INTRODUCTION}

Aquaculture is an economic activity involving the aquatic organisms farming such as fish, crustaceans, and mollusks, among others. Besides that, this activity is essential in providing high-quality protein, also helps to generate jobs and income for social welfare (Tacon \& Metian, 2013). In recent years it has increased its worldwide production significantly, accounting in 2014 for $52 \%$ of total fisheries production, the first time that aquaculture overcomes fisheries in providing food for the human population (FAO, 2016). In Mexico, this activity also presented a considerable growth rate during the last decade, with tilapia being the most important species in terms of production, reporting a $36.7 \%$ contribution to the total production of the country in 2014 (SAGARPA-INAPESCA, 2014). However, tilapia is an exotic species that was introduced to the country in 1964 , which has had a significant impact on aquatic environments (Rojas \& Mendoza, 2000).

As an alternative production, according to the policy of sustainable development, has encouraged the culture of native fish, such as Mayan cichlid, castarrica Cichlasoma urophthalmus, a fish belonging to the cichlid family distributed in southeastern Mexico with a significant commercial value. This species presents omnivorous habits with a carnivorous tendency and presents adaptation to different aquatic environments ranging from freshwater lakes to brackish lagoons and mangroves (Chávez-Lomelí et al., 1989); due to these characteristics, several investigations in aspects of reproduction, nutrition, and stocking densities have been performed (Jiménez-Martínez et al., 2009, 2012; López-Ramírez et al., 2011; Cuenca-Soria et al., 2013, 2014). However, the information about culture development is still incipient, particularly in the development of a balanced feed for larviculture that satisfies

Corresponding editor: Eduardo Ballester 
the nutritional requirements and enhances the profitability of the commercial culture.

One of the most important components in fish diets and, in larval stages are the lipids (Sargent et al., 1997; Tocher et al., 2008), which act as an energy source in addition to positively influence reproduction, survival, and growth (Sargent et al., 2002). Typically, fish oil has been used as the primary source of dietary lipids in balance diets (Turchini et al., 2009), although these raw materials are depended entirely on wild fisheries, impacting negatively by overfishing, forcing the evaluation of different lipid sources as sustainable alternatives to mitigate the impact and reduce the costs of production (Tacon \& Metian, 2008). The efforts to replace the use of fish oil by vegetable sources in balanced diets have been increasing in recent years, with the view to improve the growth, food efficiency, health, reproduction and physiology of the cultured organisms (Sargent et al., 1999; Tocher et al., 2008; Turchini et al., 2009; Nasopoulou \& Zabetakis, 2012; Zuo et al., 2015).

As an alternative, soybean oil has been used to replace fish oil, which has been evaluated in several species such as seabream (Sparus aurata), cobia (Rachycentron canadum), meagre (Argrysomus regius) and shortfin weakfish (Cynoscion parvipinnis) (Martínez-Llorens et al., 2007, Trushenski et al., 2011; Emre et al., 2016; González-Félix et al., 2016, respectively). Most of the studies have focused on isolipidic diets evaluation, testing different degrees of soybean oil substitution, nevertheless, those studies do not consider the effects between lipid levels and source type on parameters such as growth, survival, activity of digestive enzymes and expression of lipogenic genes, particularly during larval stages. Therefore, the presents study aimed to evaluate the effect of different dietary lipid levels as well as fish oil and soy lecithin on growth, enzymatic activity and some lipogenic gene expression during the larval stage of $C$. urophthalmus.

\section{MATERIALS AND METHODS}

\section{Fish and experimental conditions}

The larvae of $C$. urophthalmus $(3.24 \pm 0.21 \mathrm{mg}$, average wet weight, $\mathrm{n}=810$ ) were obtained from a batch of broodstock from the Tropical Aquaculture Laboratory from DACBIOL-UJAT and were randomly distributed in 27 circular tanks $(60 \mathrm{~cm}$ in diameter, with $40 \mathrm{~L}$ of water), each experimental unit had a total of 30 larvae.

Tanks were connected to a recirculation system composed by a sand filter, biological filter, $700 \mathrm{~L}$ water reservoir, and a $1 \mathrm{HP}$ water peripheral pump. For water quality management, $10 \%$ of the water was replaced daily, where remained feces and food were removed by siphoning procedure. Air was supplied to each tank by diffuser stones connected to a blower of $2 \mathrm{HP}$ of capacity. The temperature and dissolved oxygen were recorded daily $\left(30.0 \pm 0.1^{\circ} \mathrm{C}\right.$ and $5.2 \pm 1.2 \mathrm{mg} \mathrm{L}^{-1}$ respectively) with YSI oxymeter (556), during the 45 days of experimentation. The feed was supplied to each tank four times a day $(9: 00,12: 00,15: 00$ and 18:00 h) to apparent satiety.

\section{Experimental design}

A completely randomized bifactorial $(2 \times 4)$ experiment was designed, with lipid sources (fish oil: FO or soybean lecithin: LO) as a first factor, and as second factor the lipid concentration in the diets with four levels $(10,15,20$ and 25\%), in addition, a commercial diet for tilapia (Silver Cup, 15\% lipids) was used as a control. All treatments were evaluated by triplicate. The dependent variables evaluated were the average weight and total length growth, survival, digestive enzymatic activity (alkaline proteases, acid proteases, trypsin, chymotrypsin, and lipase), as well as the relative expression of lipogenic genes: acetyl CoA carboxylase (ACC1) and fatty acid synthase (FAS).

\section{Diets preparation}

Eight isoproteic diets were formulated with the Mixittwin v5.0 software, which differed in lipid source and dietary lipid levels (Table 1). The elaboration of the diets was performed following the protocol reported by Álvarez-González et al. (2001). For the manufacture of the diets, the macro-ingredients (fish meal, whole sorghum meal, beef meal, and chicken meal) were sieved with a $500 \mu$ screen to homogenize the particle size, then mixed with a blender industry (Bathamex, 178716) for $20 \mathrm{~min}$, then added the premixes of vitamins and minerals, vitamin $\mathrm{C}$, and grenetin and mixed for $20 \mathrm{~min}$. Finally, the liquid ingredients, the soluble fish and the oil (fish or soybean lecithin depending on the diet) were added, the mixture was again transferred to a mixing process for $20 \mathrm{~min}$, at which time adding distilled water until it had an adequate consistency. Once the paste was obtained, it was passed through a meat mill of $1 \mathrm{HP}$ (Torrey, M22RI) with a $5 \mathrm{~mm}$ sieve; the pellets were cut manually, later to be dried in an oven (Coriat, HC-35-D) at $60^{\circ} \mathrm{C}$ for $12 \mathrm{~h}$. The diets were placed in plastic bags and kept in refrigeration $\left(4^{\circ} \mathrm{C}\right)$ until use.

\section{Growth and survival}

In order to evaluate larvae growth, biometrics was performed at 15, 30 and 45 days. Fish were weighed (wet weight) with an analytical balance (DNA, model 
Table 1. Ingredients of experimental diets for Cichlasoma urophthalmus larvae with two lipid sources (FO: fish oil and LO: soybean lecithin oil) and four different levels (10, 15, 20 and 25\%). ${ }^{a}$ Proteínas Marinas y Agropecuarias S.A. de C.V., Guadalajara, Jalisco; ${ }^{\mathrm{b}}$ GALMEX Comercializadora de Insumos Agrícolas S.A. de C.V., Villahermosa, Tabasco; ${ }^{\text {PPronat }}$ Ultra, Mérida, Yucatán; ${ }^{\mathrm{d} D} \mathrm{D}^{\prime}$ gari, Productos Alimenticios y Dietéticos Relámpago, S.A. de C.V., Tlalpan, D.F.; ${ }^{\mathrm{e} C o n s o r c i o}$ Super S.A. de C.V., Guadalajara, Jalisco; ${ }^{\mathrm{f}} \mathrm{DSM}^{\circledR}$ C-EC (Roche) agente activo de $35 \%$.

\begin{tabular}{lrrrrrrrr}
\hline Ingredients $(\mathrm{g} / 100 \mathrm{~g}$ diets $)$ & FO10 & FO15 & FO20 & FO25 & LO10 & LO15 & LO20 & LO25 \\
\hline Fish meal & 30.10 & 30.10 & 30.10 & 30.10 & 30.10 & 30.10 & 30.10 & 30.10 \\
Poultry by-products meal $^{\mathrm{a}}$ & 22.00 & 22.00 & 22.00 & 22.00 & 22.00 & 22.00 & 22.00 & 22.00 \\
Beef meal $^{\mathrm{a}}$ & 20.00 & 20.00 & 20.00 & 20.00 & 20.00 & 20.00 & 20.00 & 20.00 \\
Sorghum meal $^{\mathrm{b}}$ & 19.90 & 14.70 & 9.50 & 4.29 & 19.90 & 14.70 & 9.50 & 4.29 \\
Grenetin $^{\mathrm{d}}$ & 2.00 & 2.00 & 2.00 & 2.00 & 2.00 & 2.00 & 2.00 & 2.00 \\
Fish hydrolisates $^{\mathrm{a}}$ & 2.00 & 2.00 & 2.00 & 2.00 & 2.00 & 2.00 & 2.00 & 2.00 \\
Fish oil $^{\mathrm{a}}$ & 2.00 & 7.20 & 12.40 & 17.61 & - & - & - & - \\
Soybean lecithin $^{\mathrm{c}}$ & - & - & - & - & 2.00 & 7.20 & 12.40 & 17.61 \\
Vitamins and minerals premix $^{\mathrm{e}}$ & 1.50 & 1.50 & 1.50 & 1.50 & 1.50 & 1.50 & 1.50 & 1.50 \\
Vitamin C $^{\mathrm{f}}$ & 0.50 & 0.50 & 0.50 & 0.50 & 0.50 & 0.50 & 0.50 & 0.50 \\
\hline Nutrients (g/100 g dry matter) & & & & & & & & \\
\hline Energy (KJ g-1) & 6.45 & 7.85 & 9.20 & 10.56 & 6.39 & 7.63 & 8.99 & 10.12 \\
Protein & 49.99 & 50.53 & 49.07 & 48.61 & 50.10 & 48.79 & 48.62 & 49.01 \\
Lipids & 10.30 & 14.92 & 20.56 & 24.12 & 9.96 & 15.13 & 21.03 & 24.65 \\
Fiber & 1.34 & 1.42 & 1.30 & 1.18 & 0.97 & 1.21 & 1.24 & 1.27 \\
Ash & 11.11 & 11.02 & 10.92 & 10.83 & 10.31 & 10.54 & 11.04 & 11.34 \\
\hline
\end{tabular}

HR-250AZ, USA) and individually length measured with a digital vernier (Caliper, 677256, Spain). Growth parameters were calculated following formulas: Weight gain $(\mathrm{WG})=$ initial weight $(\mathrm{g})$ / final weight $(\mathrm{g})$; Feed conversion rate $(\mathrm{FCR})=$ food supplied $(\mathrm{g}) /$ weight gain (g); Daily growth rate $($ DGR $)=$ weight gained / days; Condition factor $(\mathrm{CF})=$ weight $(\mathrm{g}) /$ length $^{3}(\mathrm{~cm})$, Specific growth rate $(\mathrm{SGR})=[(\ln$ final weight- $\ln$ initial weight $) / 45$ days $] \times 100$ and Survival $(S)=($ final number (fish) / initial number (fish)) $\times 100$.

\section{Sampling and sample preparation}

At the end of the experiment, three larvae per tank (nine per treatment) were previously anesthetized with MS222 (tricaine metasulphonate, $0.15 \mathrm{mg} \mathrm{L}^{-1}$ ) and euthanized with a rapid dissection of the head to remove the visceral package (stomach and intestine) under cold conditions $\left(4^{\circ} \mathrm{C}\right)$. The individual wet weight of the visceral package was obtained (three larvae per replicate) and $25 \%$ of the total weight per sample was homogenized as a pool in $0.1 \mathrm{M}$ glycine- $\mathrm{HCl}$ buffer at $\mathrm{pH} 2$. The remaining $75 \%$ of the visceral package pool was homogenized in $30 \mathrm{mM}$ Tris- $\mathrm{HCl}+12.5 \mathrm{mM}$ $\mathrm{CaCl}_{2} \mathrm{pH} 7.5$ at a ratio of 1:40 (40 mL of buffer per gram of tissue) using an electric macerator (Ultra Turrax Ika T18 Basic). The homogenized tissue was centrifuged at $16,000 \mathrm{~g}$ for $15 \mathrm{~min}$ at $4^{\circ} \mathrm{C}$ (Eppendorf $5810 \mathrm{R}$ ), and the supernatant was collected and frozen at $-80^{\circ} \mathrm{C}$ until further analysis. Additionally, six larvae per treatment (two per tank) were placed in an Eppendorf tube with $0.5 \mathrm{ml}$ of RNA later and frozen to $-80^{\circ} \mathrm{C}$ until gene expression analysis.

\section{Digestive enzymatic activities}

The concentration of soluble protein in the multienzymatic extracts was measured by the technique of Bradford (1976), using a standard curve of serum bovine albumin. All samples were analyzed in triplicate. Pepsin activity was determined by the method of Anson (1938) using hemoglobin as a substrate, while total alkaline proteases activity was measured with the method described by Walter (1984) using casein as a substrate. In this sense, $20 \mu \mathrm{L}$ of enzyme extract was mixed with $1 \mathrm{~mL}$ of substrate $1 \%$ hemoglobin in solution glycine- $\mathrm{HCl} 0.1 \mathrm{M} \mathrm{pH} 2$ for pepsin and $1 \%$ casein in $100 \mathrm{mM}$ Tris- $\mathrm{HCl}$ solution 10 $\mathrm{mM} \mathrm{CaCl} 2 \mathrm{pH} 9$ for total alkaline proteases, and incubated for 90 and $30 \mathrm{~min}$ respectively, both at $37^{\circ} \mathrm{C}$. The reactions were stopped with the addition of $0.5 \mathrm{~mL}$ of trichloroacetic acid at $20 \%$, then the samples were centrifuged at $16,000 \mathrm{~g}$ at $4^{\circ} \mathrm{C}$ for $15 \mathrm{~min}$, and the absorbance was measured at $280 \mathrm{~nm}$.

Trypsin activity was measured by the method of Erlanger et al. (1961) using $1 \mathrm{mM}$ BAPNA ( $\mathrm{N}-\alpha-$ benzoyl-DL-arginine p-nitroanilide) as substrate dissolved with dimethyl sulfoxide (DMSO) in buffer 
solution $50 \mathrm{mM}$ Tris- $\mathrm{HCl}+10 \mathrm{mM} \mathrm{CaCl} 2, \mathrm{pH}$ 8.2. The samples were incubated at $37^{\circ} \mathrm{C}$ for $15 \mathrm{~min}$, and $30 \%$ acetic acid was added to stop the reaction and read with the spectrophotometer at $410 \mathrm{~nm}$.

Chymotrypsin activity was determined by the method of Del Mar et al. (1961) where SAPNA substrate ( $\mathrm{N}-\alpha$-benzoyl-DL-arginine $\mathrm{p}$-nitroanilide) was prepared with DMSO and buffered with buffer 100 $\mathrm{mM}$ Tris- $\mathrm{HCl}+10 \mathrm{mM} \mathrm{CaCl}_{2}, \mathrm{pH}$ 7.8. Incubation was performed at $37^{\circ} \mathrm{C}$ for $20 \mathrm{~min}$, and the reaction was stopped with $30 \%$ acetic acid to measure the absorbance at $405 \mathrm{~nm}$ in the spectrophotometer finally.

Lipase activity was performed by the modified method of Versaw et al. (1989), using sodium tauracholate at $100 \mathrm{mM}$, buffered with $50 \mathrm{mM}$ Tris- $\mathrm{HCl}, \mathrm{pH}$ 7.5. There was a preincubation at $37^{\circ} \mathrm{C}$ for $5 \mathrm{~min}$ and $\beta$-naphthyl caprylate (dissolved in DMSO) as substrate was added, again incubated at $37^{\circ} \mathrm{C}$ for $10 \mathrm{~min}$. Finally, the fast blue solution was added to $100 \mathrm{mM}$ (dissolved in DMSO) and incubated at $37^{\circ} \mathrm{C}$ for $5 \mathrm{~min}$, stopping the reaction with $12 \%$ TCA. A solution of ethyl acetate (ethanol 1: $1 \mathrm{v} / \mathrm{v}$ ) was added to clarify the reaction, and the absorbance was measured at $540 \mathrm{~nm}$.

One unit of enzymatic activity was defined as 1 microgram of product released per minute at $37^{\circ} \mathrm{C}$, based on the molar extinction coefficient. The following formulas were used to determine the enzymatic activity: Total activity $\left(\mathrm{U} \mathrm{mL}^{-1}\right)=($ absorbance $\times$ vol final reaction $(\mathrm{mL}) /$ (coefficient of molar extinction $\times$ time $(\mathrm{min}) \times$ vol of extract $(\mathrm{mL}))$ and the Specific activity $\left(\mathrm{U}\right.$ mg protein $\left.{ }^{-1}\right)=$ total activity / soluble protein $(\mathrm{mg})^{-1}$.

\section{Genomic expression}

For the present study, specific oligonucleotides for qRT-PCR were designed from the partial sequences of EF1, FAS, ACC1 of Atractosteus tropicus registered in the Gen Bank (Accession numbers: KT351350, KT351352, and KT351353, respectively) (Table 2). Thus, total RNA extraction was performed from a pool of larvae (six per experimental unit) according to each treatment by the Trizol Reagent method (Invitrogen, USA). The RNA concentration and purity were subsequently estimated using the 260/280 ratio using NanoDrop 1000 Spectrophotometer (Thermo Fisher Scientific, USA).

To integrity determination of the nucleic acids, electrophoresis was performed on a $1 \%$ agarose gel using an aliquot of $1 \mu \mathrm{L}$ of sample, mixed with $1 \mu \mathrm{L}$ of run buffer from each of the samples, at 100 volts in an electrophoresis chamber Mini Sub Cell GT (Bio-Rad, USA) for $30 \mathrm{~min}$. The resulting bands were visualized in a gel documentation system Molecular Imager Gel
Doc XR + Imaging System (Bio-Rad, USA). Once the integrity of the genetic material of samples was evaluated, the corresponding aliquots of each of the samples were made according to their concentration.

Subsequently, a microgram of RNA was used for reverse transcription with iScript TM Select cDNA Synthesis Kit 170-8896 (Bio-Rad, USA). Subsequently, two microliters of cDNA were used for the qPCR. The expression analysis of the ACC1 and FAS lipogenic genes was performed in a 96-well thermal cycler (CFX96 Real-Time system thermal cycle model C1000, USA). The reaction mixture was $10 \mu \mathrm{L}$, including $5 \mu \mathrm{L}$ of Eva Green, $2 \mu \mathrm{L}$ of cDNA, $2.85 \mu \mathrm{L}$ of $\mathrm{H}_{2} \mathrm{O}$ milli-Q and $0.15 \mu \mathrm{L}$ of each primer. The qRTPCR was performed under these conditions, $2 \mathrm{~min}$ at $95^{\circ} \mathrm{C}$, followed by 38 cycles of $95^{\circ} \mathrm{C}$ for $10 \mathrm{~s}, 60^{\circ} \mathrm{C}$ for $30 \mathrm{~s}$ and an extension process of $70^{\circ} \mathrm{C}$ for $5 \mathrm{~s}$. For the normalization of cDNA, the EF1 was used as a constitutive gene and was carried out in parallel with all the samples. A standard curve of each pair of primers was generated to estimate the amplification efficiencies based on known amounts of cDNA (in series of four times dilutions corresponding to cDNA transcribed from 100 to $0.1 \mathrm{ng}$ of total RNA). The relative expression of the genes was calculated by the deltadelta CT method (Pfaffl, 2001).

\section{Statistic analysis}

Data of weight, total length, survival, growth index, and enzymatic activity were analyzed by normality and homoscedasticity assumptions when they comply with assumptions a two-way ANOVA (lipid levels and lipid source) were performed, where the differences were analyzed with a Tukey test. The sine-arc transformations were used for the data in percentage and thus satisfy the ANOVA assumptions. For gene expression, the Kruskal-Wallis tests were carried out, and differences found were analyzed using a Nemenyi test. For all cases, $P<0.05$ significance values were used. All statistical analyses were carried out with the Statgraphics Centurion XVI program.

\section{RESULTS}

\section{Larval growth}

The two-way ANOVA indicates that type and level of oil presents, had significant effect $(P<0.05)$ on the average weight, which indicated a greater weight in fish fed diets containing soybean lecithin oil (LO) $(0.25 \pm$ $0.02 \mathrm{~g}$ ) compared with fish oil diets treatments (FO) $(0.20 \pm 0.01 \mathrm{~g})$. Regarding the level of lipids, those fish that received higher lipid levels $(15,20$ and 25\%) recorded the highest statistical weights $(P>0.05)$. On the other hand, for total length, only significant diffe- 
Table 2. Oligonucleotides used for qPCR analysis in Cichlasoma urophthalmus larvae.

\begin{tabular}{lllc}
\hline Gene & Forward oligonucleotide $\left(5^{\prime}-3^{\prime}\right)$ & Reverse oligonucleotide $\left(5^{\prime}-3^{\prime}\right)$ & $\begin{array}{c}\text { Expected } \\
\text { fragment }(\mathrm{pb})\end{array}$ \\
\hline EF1 & CCTGCAGGACGTCTACAAGATCG & GACCTCAGTGGTCACGTTGGA & 120 \\
FAS & GACGGCATGTTGGAGAACCTG & CTCACCGAGGAGAAGACCACA & 139 \\
ACC1 & GTCCAGCTGGTGCAGAAGTA & CGCACTTGTCATAATGTCCGTTC & 123 \\
\hline
\end{tabular}

rences were found $(P<0.05)$ in the level of lipid inclusion, where the fish fed with 15, 20 and $25 \%$ lipid percentage presented the greatest lengths $(P<0.05)$. In this sense, the average value of weight in total interaction showed that fish fed with LO15 and LO20 $\operatorname{diets}(0.32 \pm 0.05$ and $0.29 \pm 0.03$ g respectively) recorded the highest values compared with fish fed the LO10 and control diets $(0.11 \pm 0.01$ and $0.12 \pm 0.01 \mathrm{~g}$ respectively) (Fig. 1a). In reference to the interaction of average total length, the fish fed with the diets LO20, $\mathrm{LO} 15, \mathrm{FO} 25, \mathrm{FO} 20$ and $\mathrm{LO} 25(2.34 \pm 0.09,2.31 \pm 0.10$, $2.30 \pm 0.04,2.24 \pm 0.01$ and $2.21 \pm 0.09$ g respectively) were statistically larger $(P<0.05)$, than fish fed with LO10, control and FO10 diets $(1.73 \pm 0.11,1.72 \pm 0.05$ and $1.71 \pm 0.13 \mathrm{~g}$ respectively) (Fig. $1 \mathrm{~b}$ ).

\section{Feed quality indexes and survival}

The treatments that showed a better performance in WG and DGR were larvae fed with diets LO15 and LO20 $(0.32 \pm 0.1$ and $0.29 \pm 0.06,7.08 \pm 2.29$ and 6.48 $\pm 1.34 \mathrm{~g}$ respectively), in contrast to larvae fed with LO10 and the commercial diets, which showed the lowest values $(0.11 \pm 0.09$ and $0.12 \pm 0.01,2.53 \pm 0.49$ and $2.74 \pm 0.21 \mathrm{~g}$ respectively). For the SGR, the best results were for larvae fed with LO15, LO20, and LO25 $(10.25 \pm 0.79,10.19 \pm 0.43$ and $10.04 \pm 0.55 \mathrm{~g})$, while larvae fed LO10 and the commercial diets showed the lowest values $(7.87 \pm 0.4$ and $8.13 \pm 0.17$. $\mathrm{g}$ respectively). For the FCR the larvae fed LO15 diet showed the best efficiency $(11.6 \pm 3.25)$, compared with larvae fed FO25, which were least efficient (35.9 $\pm 5.24)(P<0.05$, Table 3$)$.

Soybean lecithin had a positive effect on the DGR and FCR indexes, while in SGR, CF and S did not present statistical differences concerning fish oil $(P>$ $0.05)$. The level of lipids in the diet had a significant effect for DGR, SGR and FCR being 15, 20, and 25\% the best results. However, $\mathrm{CF}$ and $\mathrm{S}$ indices did not show significant differences $(P<0.05$, Table 3$)$.

\section{Digestive enzyme activities}

The evaluation of the digestive enzymatic activities of nine $C$. urophthalmus larvae diets indicates statistical differences for trypsin and chymotrypsin activities, where LO20 and LO25 presented the highest values
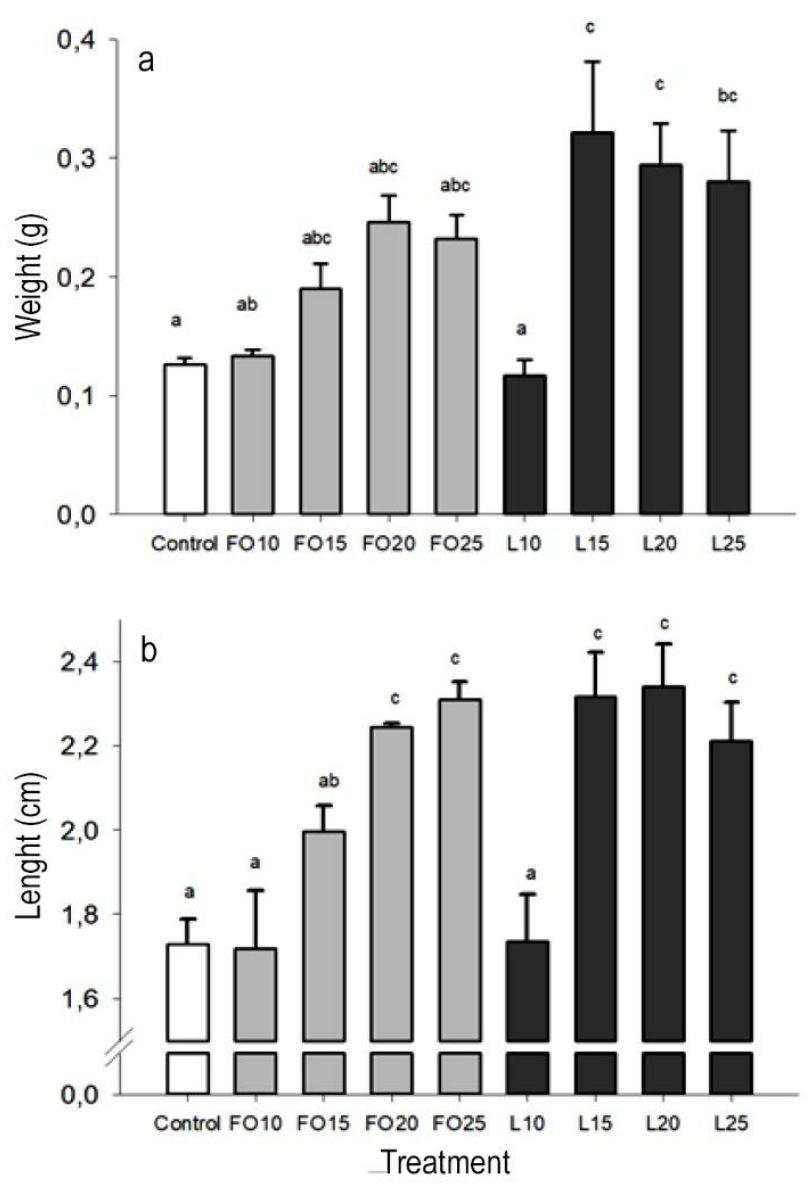

Figure 1. a) Growth in weight, b) total length of larvae of C. urophthalmus fed diets with different levels and lipid sources in 45 days. Mean values and standard error (bars) of three replicates for each treatment (Control, FO: 10, 15, 20 and 25\%, and LO: 10, 15, 20 and 25\%, lipid source: level of inclusion). Different letters above the bars indicate statistically significant differences $(P<0.05)$.

$(P<0.05)$ (Table 4). Meanwhile, soybean lecithin produced a significant increase $(P<0.05)$ in the activity of total alkaline proteases, chymotrypsin, trypsin, and lipase compared with larvae fed with diets containing fish oil despite lipid level. Although the activity of acidic protease (pepsin) was not affected by the type of lipid included in the diets. The data indicate that there is no significant interaction effect for lipid level and oil source for any digestive enzyme $(P>0.05)$. 
Table 3. Growth performance of Cichlasoma urophthalmus fed different diets containing two sources of lipids (FO: fish oil and LO: soybean lecithin oil) in four different levels $(10,15,20$ and 25\%). The treatment values are presented with the mean \pm standard deviation. Values in columns with different letters as exponents indicate significant differences $(P<0.05)$. WG: weight gain, DGR: daily growth rate, SGR: specific growth rate, FCR: feed conversion rate, CF: condition factor, S: survival.

\begin{tabular}{|c|c|c|c|c|c|c|c|c|c|}
\hline \multicolumn{10}{|c|}{ Treatments } \\
\hline Indexes & LO10 & LO15 & LO20 & LO25 & FO10 & FO15 & $\mathrm{FO} 20$ & $\mathrm{FO} 25$ & Commercial \\
\hline WG (g) & $0.11 \pm 0.02^{\mathrm{a}}$ & $0.32 \pm 0.1^{\mathrm{c}}$ & $0.29 \pm 0.06^{\mathrm{c}}$ & $0.28 \pm 0.07^{\mathrm{bc}}$ & $0.13 \pm 0.01^{\mathrm{ab}}$ & $0.19 \pm 0.04^{\mathrm{abc}}$ & $0.24 \pm 0.04^{\mathrm{abc}}$ & $0.23 \pm 0.04^{\mathrm{abc}}$ & $0.12 \pm 0.01^{\mathrm{a}}$ \\
\hline DGR (mg) & $2.5 \pm 0.5^{\mathrm{a}}$ & $7.1 \pm 2.3^{\mathrm{c}}$ & $6.5 \pm 1.3^{\mathrm{c}}$ & $6.2 \pm 1.6^{\mathrm{bc}}$ & $2.9 \pm 0.2^{\mathrm{ab}}$ & $4.1 \pm 0.8^{\mathrm{abc}}$ & $5.4 \pm 0.9^{\mathrm{abc}}$ & $5.1 \pm 0.8^{\mathrm{abc}}$ & $2.7 \pm 0.2^{\mathrm{a}}$ \\
\hline SGR & $7.9 \pm 0.4^{\mathrm{a}}$ & $10.2 \pm 0.8^{\mathrm{c}}$ & $10.2 \pm 0.4^{\mathrm{c}}$ & $10.0 \pm 0.5^{\mathrm{c}}$ & $8.4 \pm 0.16^{\mathrm{ab}}$ & $9.1 \pm 0.5^{\mathrm{abc}}$ & $9.7 \pm 0.3^{c}$ & $9.5 \pm 0.3^{b c}$ & $8.1 \pm 0.2^{\mathrm{a}}$ \\
\hline FCR & $28.4 \pm 6.1^{\text {cde }}$ & $11.6 \pm 3.2^{\mathrm{a}}$ & $14.4 \pm 1.5^{\mathrm{ab}}$ & $23.6 \pm 6.0^{\mathrm{abcd}}$ & $34.1 \pm 3.4^{\mathrm{de}}$ & $21.4 \pm 4.3^{\mathrm{abc}}$ & $22.3 \pm 3.2^{\mathrm{abcd}}$ & $35.9 \pm 5.2^{\mathrm{eg}}$ & $24.3 \pm 2.9^{\text {bcde }}$ \\
\hline $\mathrm{CF}$ & $2.3 \pm 0.4$ & $2.5 \pm 0.4$ & $2.3 \pm 0.1$ & $2.6 \pm 0.6$ & $2.9 \pm 1.2$ & $2.4 \pm 0.4$ & $2.2 \pm 0.3$ & $1.9 \pm 0.3$ & $2.5 \pm 0.5$ \\
\hline S (\%) & $82 \pm 8$ & $89 \pm 5$ & $83 \pm 3$ & $87 \pm 8$ & $71 \pm 5$ & $83 \pm 9$ & $83 \pm 6$ & $77 \pm 3$ & $88 \pm 7$ \\
\hline
\end{tabular}

Table 4. Enzymatic activity of Cichlasoma urophthalmus fed different diets containing two sources of lipids (P: fish oil and L: soybean lecithin) and four different levels (10, 15, 20 and 25\%). The values of the main effects and treatments are presented with the mean \pm standard deviation. Values in columns with different letters indicate significant differences $(P<$ 0.05). The $P$-value of a two-way ANOVA concerning the source and level of lipids and their interaction is also presented.

\begin{tabular}{|c|c|c|c|c|c|c|c|c|c|}
\hline \multicolumn{10}{|c|}{ Treatments } \\
\hline Activity (U mg protein ${ }^{-1}$ ) & LO10 & LO15 & LO20 & LO25 & FO10 & FO15 & FO20 & $\mathrm{FO} 25$ & Commercial \\
\hline Acid proteases & $6.5 \pm 4.4$ & $5.1 \pm 3.5$ & $10.2 \pm 3.8$ & $10.5 \pm 2.6$ & $2.3 \pm 1.3$ & $7.1 \pm 2.1$ & $13.6 \pm 79$ & $6.4 \pm 7.0$ & $3.3 \pm 1.0$ \\
\hline Alkaline proteases & $57.5 \pm 30.6$ & $54.7 \pm 3$ & $75.4 \pm 27.6$ & $61.0 \pm 32.9$ & $52.8 \pm 23.9$ & $33.6 \pm 2.0$ & $36.7 \pm 7.0$ & $21.1 \pm 2.7$ & $34.8 \pm 10.4$ \\
\hline Chymotrypsin & $29.0 \pm 16.1^{\mathrm{a}}$ & $22.8 \pm 2.2^{\mathrm{a}}$ & $65.4 \pm 4.6^{\mathrm{cb}}$ & $70.4 \pm 11.2^{\mathrm{c}}$ & $26.1 \pm 10.6^{\mathrm{a}}$ & $23.1 \pm 3.4^{\mathrm{a}}$ & $41.1 \pm 2.6^{\mathrm{a}}$ & $23.4 \pm 6.1^{\mathrm{a}}$ & $42.7 \pm 1.3^{\mathrm{ab}}$ \\
\hline Trypsin & $73.8 \pm 32.7^{a b}$ & $75.8 \pm 9.9^{\mathrm{b}}$ & $106.3 \pm 15.5^{\mathrm{ab}}$ & $96.1 \pm 41.9^{\mathrm{ab}}$ & $80.8 \pm 58.4^{\mathrm{ab}}$ & $46.6 \pm 21.5^{\mathrm{ab}}$ & $42.2 \pm 11.1^{\mathrm{ab}}$ & $24.2 \pm 6.3^{\mathrm{a}}$ & $66.2 \pm 41.6^{\mathrm{ab}}$ \\
\hline Lipase & $57.5 \pm 31.2$ & $95.2 \pm 59.8$ & $106.9 \pm 56.5$ & $105.8 \pm 19$ & $55.2 \pm 28.4$ & $23.9 \pm 5.3$ & $65.7 \pm 19.0$ & $46.2 \pm 16.6$ & $71.4 \pm 42.0$ \\
\hline
\end{tabular}

\section{Expression of FAS and ACC1 genes}

The relative expression of FAS and ACC1 showed significant differences (Nemenyi, $P<0.05$ ) between oil sources, being lower in the fish fed with diets containing soybean lecithin (Fig. 2) compared with larvae fed with diets containing fish oil. On the other hand, the control diet presented the highest values, followed by fish oil diets, FO25, FO20, FO10, and FO15 respectively.

\section{DISCUSSION}

The present study was based on the total weaning of $C$. urophthalmus larvae with inert diets from their first feeding (yolk absorption and mouth opening). In this aspect, the larvae had no problems in adapting to artificial feeds since their first feeding, which allows eliminating the use of Artemia nauplii, which have been previously used (Jiménez-Martínez et al., 2009; LópezRamírez et al., 2011). In this aspect, the disuse of live feeds is an advantage for larviculture due to the high cost of Artemia cysts and reducing the technical personnel for the production of live feed. It is important to consider that development of these experimental diets for $C$. urophthalmus larvae it is based on previous digestive physiology and in vitro digestibility studies (Cuenca-Soria et al., 2013, 2014), in such a way they cover the nutritional requirements of the species (Martínez-Palacios, 1987).
Based on the results obtained during this experiment, it is considered that the replacement of fish oil with soybean lecithin at a level between 15 and $20 \%$ in the diet provides the necessary energy for optimal development, reflected in better growth performance, survival and feed conversion factor for C. urophthalmus larvae. Our results, in terms of weight gain and survival, were quite similar to those obtained by LópezRamírez et al. (2011), and Jiménez-Martínez et al. (2009). However, they use Artemia nauplii as food for the first 15 days after hatching, which differs from our experiment because we provided just the artificial diet without any live food that represents an improvement for the culture of this species.

In this regard, the use of lipids in fish diets has an impact on food processing, growth, and survival of fish (Jauncey, 1982). An excess of lipids does not allow an appropriate granulation of the fish diet, obtaining a high pasty consistency that could not be accepted by fish larvae feed with FO25 diet presented lower yield, reflected in an increase in the FCR. In this same sense, FCR improved significantly with the use of soybean lecithin, which was previously reported in turbot Psetta maxima (Regost et al., 2003), pikeperch Sander lucioperca (Hamza et al., 2008) and barramundi Lates calcarifer (Salini et al., 2016). It is worth mentioning that in most studies, diets are made with a partial substitution of fish oil, except Cahu et al. (2003), who made a total substitution obtaining excellent results about 


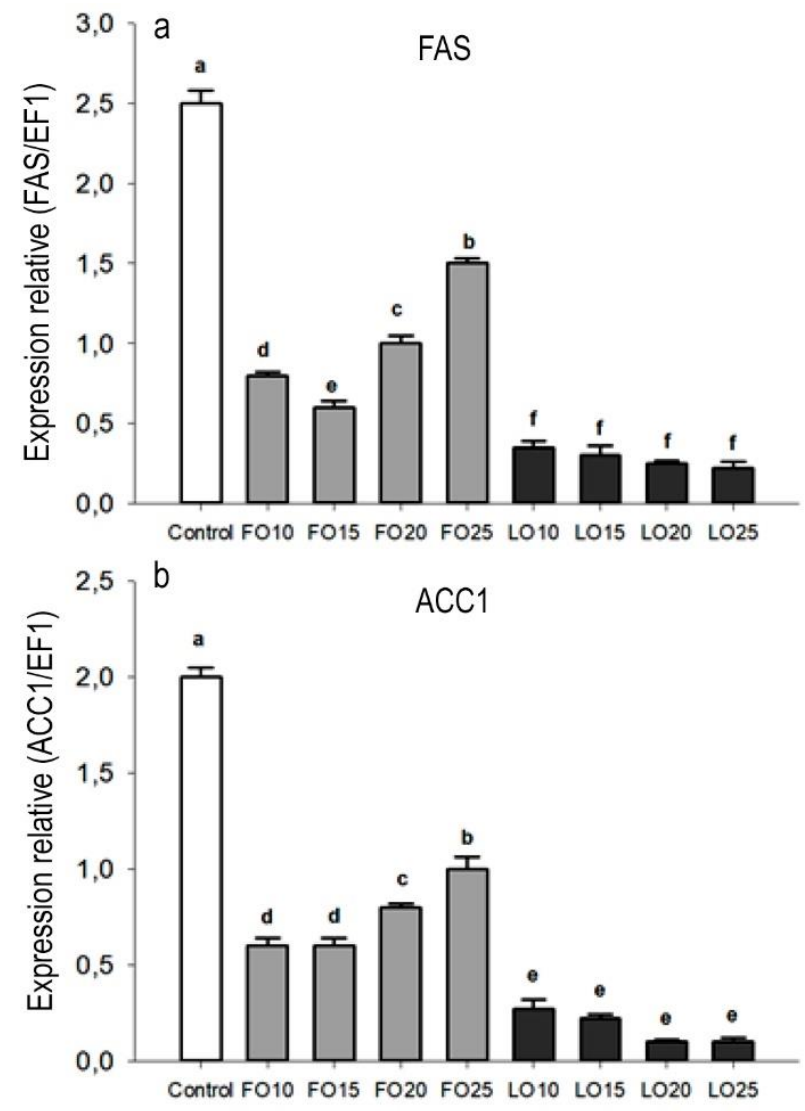

Figure 2. a) Relative expression of FAS, b) ACC1 of $C$. urophthalmus larvae fed diets with different levels and lipid sources in 45 days. Mean values and standard error (bars) of three replicates for each treatment (Control, FO: 10, 15, 20 and 25\%, and LO: 10, 15, 20 and 25\%, lipid source: level of inclusion). Different letters above the bars indicate statistically significant differences $(P<0.05)$.

the growth and survival in sea bass Dicentrarchus labrax.

Considering the above-mentioned, soybean lecithin is a byproduct derived from crude soybean oil, from a process called degumming, which consists in separating the phospholipids from the oil, obtaining at the end a thick consistency with a high proportion of phospholipids (Daniel, 2004). Phospholipids contain a phosphoric residue, an alcohol and two fatty acids, with a high concentration of linoleic acid (LA; 18: $2 \mathrm{n}-6$ ) and $\alpha$-linolenic acid (ALA; 18: 3 n-3), considered essential in the diet of fish (Turchini et al., 2009), since they do not possess the biosynthesis capability and therefore, cannot be produced by the Novo LA and ALA. Thus, a nutritional disadvantage of soybean lecithin is that it lacks highly polyunsaturated fatty acids such as eicosapentaenoic acid (EPA) and docosahexaenoic acid (DHA), which are related to the formation of structural membranes and processes. If these essential fatty acids are not present or are limited in the diet, could affect the growth and survival of fish larvae, particularly in marine species. Thus, these two fatty acids are highly necessary for marine fish larvae and very susceptible to oxidation (Izquierdo et al., 2003; $\mathrm{Ng}$ et al., 2007). Therefore the use of fish oils in marine finfish diets is usually required. Although it should be noted that in the case of larvae of $C$. urophthalmus, it does not seem a problem to perform the total substitution of fish oil for soybean lecithin, possibly because some freshwater fish species such as the carps, possess the capacity to elongate and desaturate short-chain and monounsaturated fatty acids from the Novo (Turchini et al., 2009).

The rate of transcription of genes associated with the synthesis of fatty acids (FAS and ACC1) were statistically lower in the fish fed the diets containing soybean lecithin. In this regard, previous studies have shown that diets rich in PUFA such as DHA or EPA and a high level of ALA inhibit the expression of FAS, which have been detected in common carp Cyprinus carpio, rainbow trout Oncorhynchus mykiss, and Atlantic salmon Salmo salar (Peng et al., 2014). By regulating this route, these fatty acids promote a change in the synthesis of lipids and their storage. It is considered that the experimental diets used for $C$. urophthalmus larvae feeding may have contained a high concentration of ALA, while the fish oil diets possibly had a lower quality concerning high oxidation of their fatty acids that could partially explain our results.

Instead, soybean lecithin contains different classes of phospholipids, among which phosphatidylcholine (PC) and phosphatidylethanolamine (PE) stand out for their greater proportion, with PC generally having a greater effect in promoting the growth of fish. Thus, phospholipids are considered primordial precursors for the conformation of the cellular membranes indispensable for the formation of tissues during the first larval stages (Tocher et al., 2008). In addition, their presence in diets helps to improve the emulsification of other lipids (Coutteau et al., 1997; Hung et al., 1997) and their subsequent digestion in the intestine of fish (Craig \& Gatlin, 1997; Kasper \& Brown, 2003), which helps to improve the growth and survival (Kanazawa et al., 1985; Kanazawa, 1993; Cahu et al., 2003; Gisbert et al., 2005; Taylor et al., 2015, Salini et al., 2016). Based on our results, the effect of soybean lecithin in diets for C. urophthamus larvae, helps to improve the growth and feed quality indexes, which in general could be attributed to the presence of phospholipids from soybean lecithin, promoting better growth and survival, and could prevent malformations in fish larvae (Cahu et al., 2003). In this sense, Sargent et al. (2002) mention that in their natural environment, fish larvae ingest 
natural live feed (cladocerans, copepods, among others), whose predominant lipids are the phospholipids.

Regarding the activity of acidic proteases, there were no significant differences between the treatments, in contrast to that reported by Lin \& Luo (2011) where they found an increase in the activity of this enzyme by increasing soybean lecithin in the diet of tilapia hybrids (Oreochromis niloticus $\mathrm{x} O$. aureus). The acid protease (pepsin) is secreted by the stomach and promotes the acceleration of digestion processes, which increases the hydrolysis of proteins, helping the alkaline digestive proteases, located in the intestine, release short peptides and amino acids for their absorption by the enterocytes. It should be noted that larvae of $C$. urophthalmus present a digestion of alkaline proteases from yolkabsorption (López-Ramírez et al., 2011), and at day 9 after the hatching, the stomach appears, thus enhancing its protein hydrolysis capacity (Cuenca-Soria et al., 2014), which indicates that its digestive system is fully developed.

In other order of ideas, trypsin and chymotrypsin in C. urophthalmus larvae showed high activities in fish fed with soybean lecithin diets, at a level of 15 and 20\% respectively. The increment of these pancreatic enzymes may be correlated with the high content of ALA, since C18 fatty acids such as LA and oleic acid, are involved in the secretion of pancreatic enzymes (Shintani et al., 1995). Meanwhile, larvae fed diets containing fish oil had a deficient use of nutrients from the feed, reflected in lower values of trypsin activity (Ueberschar, 1995; Cara et al., 2007). Also, higher values of trypsin were presented with respect to chymotrypsin for all, which is an indication of an optimal quality of the food supplied (Moyano et al., 2006). In this sense, it has been proposed that the relationship between trypsin and chymotrypsin indicate the nutritional status of fish, so that high levels of trypsin in relation to chymotrypsin have been correlated with enough protein in the diet, while in the opposite case it is correlated with hunger or lack of fed (Blier et $a l ., 2002)$. In the case of lipase, where the activity in the fish fed with diets containing soybean lecithin, there was a tendency reflecting a higher efficiency in obtaining energy for growth with respect to fish fed diets with fish oil. This also can be related with the efficiency to release fatty acids from phospholipids that can be used as well as an energy source also to the cell and organelle membrane regeneration during the hypertrophy and hyperplasia process during somatic growth of fish larvae (Cahu et al., 2009).

In conclusion, the use of soybean lecithin oil as the primary source of lipids, at a concentration of $15 \%$, in the diet of $C$. urophthalmus larvae, represents a viable alternative for the feeding of this species. Not only because of its positive yields in growth, but also in a possible cost reduction for the elaboration of diets, and the possibility to be used as the first feeding for larviculture of the species.

\section{ACKNOWLEDGMENTS}

The author thanks the National Council of Science and Technology (CONACYT) for the support through the grant awarded during the completion of this postgradduate course. The project entitled "Fortalecimiento de la Maestría en Ciencias Ambientales para su permanencia en el Padrón Nacional de Posgrados de Calidad del CONACYT' Key: TAB-2014-C29-245836" for partially support research stay at Universidad del Papaloapán.

\section{REFERENCES}

Álvarez-González, C.A., Civera-Cerecedo, R., OrtizGalindo, S., Dumas, J.L., Moreno-Legorreta, M. \& Grayeb-Del Alamo, T. 2001. Effect of dietary protein level on growth and body composition of juvenile spotted sand bass, Paralabrax maculatofasciatus, fed practical diets. Aquaculture, 194: 151-159.

Blier, P.U., Lemieux, H. \& Devlin, R.H. 2002. Is the growth rate of fish set by digestive enzymes or metabolic capacity of the tissues? Insight from transgenic coho salmon. Aquaculture, 209: 379-384.

Bradford, M.M. 1976. A rapid and sensitive method for the quantization of microgram quantities of protein utilizing the principle of protein-dye binding. Analytical Biochemistry, 72: 248-254.

Cahu, C.L., Zambonino-Infante, J.L. \& Barbosa, V. 2003. Effect of dietary phospholipid level and phospholipid : neutral lipid value on the development of sea bass. British Journal of Nutrition, 90: 20-28.

Cahu, C.L., Gisbert, E., Villeneuve, L.A.N., Morais, S., Hamza, N., Wold, P.-A. \& Zambonino-Infante, J.L. 2009. Influence of dietary phospholipids on early ontogenesis of fish. Aquaculture Research, 40: 989999. doi.org/10.1111/j.1365-2109.2009.02190.x

Cara, B., Moyano, F.J., Zambonino-Infante, J.L. \& Fauvels, C. 2007. Trypsin and chymotrypsin as indicators of nutritional status of post-weaned sea bass larvae. Journal of Fish Biology, 70: 1798-1808. doi.org/10.1111/j.1095-8649.2007.01457.x

Chávez-Lomelí, M.O., Mattheeuws, A.E. \& Pérez, M.H. 1989. Biología de los peces del Río San Pedro en vista de determinar su potencial para la piscicultura. INREB-FUCID, Veracruz. 
Coutteau, P., Geurden, I., Camara, M.R., Bergot, P. \& Sorgeloos, P. 1997. Review on the dietary effects of phospholipids in fish and crustacean larviculture. Aquaculture, 155: 149-164.

Craig, S.R. \& Gatlin, D.M. 1997. Growth and body composition of juvenile red drum (Sciaenops ocellatus) fed diets containing lecithin and supplemental choline. Aquaculture, 151: 259-267.

Cuenca-Soria, C.A., Álvarez-González, C.A., OrtizGalindo, J.L., Nolasco-Soria, H., Tovar-Ramírez, D., Guerrero-Zárate, R., Castillo-Domínguez, A., PereraGarcía, M.A., Hernández-Gómez, R. \& Gisbert, E. 2014. Partial characterization of digestive proteases of the Mayan cichlid Cichlasoma urophthalmus. Fish Physiology and Biochemistry, 40(3): 689-699. doi.org/10.1007/s10695-013-9876-5

Cuenca-Soria, C.A., Álvarez-González, C.A., OrtizGalindo, J.L., Tovar-Ramírez, D., Guerrero-Zárate, R., Aguilar-Hernández, S. \& Gisbert, E. 2013. Histological development of the digestive system of Mayan cichlid Cichlasoma urophthalmus. Journal of Applied Ichthyology, 29: 1304-1312. doi.org/10.1111/ jai.12307

Daniel, K.T. 2004. Soy lecithin: From sludge to profit. [https://www.westonaprice.org/health-topics/soy-alert/ soy-lecithin-from-sludge-to-profit/]. Reviewed: 20 November 2017.

Del Mar, E.G., Largman, C., Brodrick, J. \& Geokas, M. 1961. A sensitive new substrate for chymotrypsin. Analytical Biochemistry, 99: 316-320.

Emre, Y., Kurtoğlu, A., Emre, N., Güroy, B. \& Güroy, D. 2016. Effect of replacing dietary fish oil with soybean oil on growth performance, fatty acid composition and hematological parameters of juvenile meagre Argyrosomus regius. Aquaculture Research, 47: 22562265. doi.org/10.1111/are.12677

Erlanger, B., Kokowsky, N. \& Cohen, W. 1961. The preparation and properties of two new chromogenic substrates of trypsin. Archives of Biochemistry and Biophysics, 95: 271-278.

Gisbert, E., Villeneuve, L., Cahu, C.L. \& ZamboninoInfante, J.L. 2005. Dietary phospholipids are more efficient than neutral lipids for long-chain polyunsaturated fatty acid supply in European sea bass (Dicentrarchus labrax) larval development. Lipids, 40(6): 609-618.

González-Félix, M.L., Maldonado-Othón, C.A. \& PerezVelazquez, M. 2016. Effect of dietary lipid level and replacement of fish oil by soybean oil in compound feeds for the shortfin corvina (Cynoscion parvipinnis). Aquaculture, 454: 217-228.

Hamza, N., Mhetli, M., Ben, I., Cahu, C. \& Kestemont, P. 2008. Effect of dietary phospholipid levels on performance, enzyme activities and fatty acid composition of pikeperch (Sander lucioperca) larvae. Aquaculture, 275: 274-282.

Hung, S.S.O., Berge, G.M. \& Storebakken, T. 1997. Growth and digestibility of soya lecithin and choline chloride in juvenile Atlantic salmon. Aquaculture Nutrition, 3: 141-144.

Izquierdo, M., Obach, A., Arantzamendi, L., Montero, D. \& Robaina, L. 2003. Dietary lipid sources for seabream and seabass : growth performance, tissue composition, and flesh quality. Aquaculture International, 9: 397-407.

Jauncey, K. 1982. The effects of varying dietary protein level on the growth, food conversion, protein utilization and body composition of juvenile tilapia (Sarotherodon mossambicus). Aquaculture, 27: 43-54.

Jiménez-Martínez, L.D., Álvarez-González, C.A., Contreras-Sánchez, W.M., Márquez-Couturier, G., Arias-Rodríguez, L. \& Almeida-Madrigal, J.A. 2009. Evaluation of larval growth and survival in Mexican mojarra, Cichlasoma urophthalmus, and Bay Snook, Petenia splendida, under different initial stocking densities. Journal of the World Aquaculture Society, 40(6): 753-761.

Jiménez-Martínez, L.D., Jesús-Contreras, R., AriasRodríguez, L., Álvarez-González, C.A., CarmonaDíaz, E., De la Cruz-Hernández, E.N. 2012. Efecto de la salinidad en larvas de la mojarra castarrica Cichlasoma urophthalmus. Kuxulkab, 18(34): 45-50.

Kanazawa, A., Teshima, S. \& Sakamoto, M. 1985. Effects of dietary bonito-egg phospholipids and some phospholipids on growth and survival of the larval ayu, Plecoglossus altivelis. Zeitschrift fur Angewandte Ichthyologie, 4: 165-170.

Kanazawa, A. 1993. Essential phospholipids of fish and crustaceans. In: Kaushik, S.J. \& Luquet, P. (Eds.). Fish nutrition in practice. INRA, Paris, pp. 519-530.

Kasper, C.S. \& Brown, P.B. 2003. Growth improved in juvenile Nile tilapia fed phosphatidylcholine. North American Journal of Aquaculture, 65: 39-43.

Lin, S. \& Luo, L. 2011. Effects of different levels of soybean meal inclusion in replacement for fish meal on growth, digestive enzymes, and transaminase activities in practical diets for juvenile tilapia, Oreochromis niloticus x $O$. aureus. Animal Feed Science and Technology, 168(1-2): 80-87.

López-Ramírez, G., Cuenca-Soria, C.A., ÁlvarezGonzález, C.A., Tovar-Ramírez, D., Ortiz-Galindo J.L., Perales-García, N. \& Moyano, F.J. 2011. Development of digestive enzymes in larvae of Mayan cichlid Cichlasoma urophthalmus. Fish Physiology and Biochemistry, 37: 197-208. doi.org/10.1007/ s10695-010-9431-6

Martínez-Llorens, S., Vidal, A.T., Moñino, A.V., Torres, M.P. \& Cerdá, M.J. 2007. Effects of dietary soybean oil concentration on growth, nutrient utilization and 
muscle fatty acid composition of gilthead sea bream (Sparus aurata L.). Aquaculture Research, 38: 76-81.

Martínez-Palacios, C.A. 1987. Aspects of the biology of Cichlasoma urophthalmus (Gunter) with particular reference to its culture. Ph.D. Thesis, University of Stirling, $321 \mathrm{pp}$.

Moyano, F.J. 2006. Bioquímica digestiva en especies acuicultivadas: aplicaciones en nutrición. In: Cruz, S.E., Ricque, M.R., Tapia, S.M., Nieto, L.M.G., Villareal, C.D.A., Puello, C.A.C. \& García, O.A. (Eds.). Avances en nutrición acuícola. VIII Simposium Internacional de Nutrición Acuícola. Universidad Autónoma de Nuevo León, pp. 396-409.

Nasopoulou, C. \& Zabetakis, I. 2012. Benefits of fish oil replacement by plant originated oils in compouned fish feeds. A review. LWT-Food Science and Technology, 47: 217-224.

Ng, W.K., Tocher, D.R. \& Bell, J.G. 2007. The use of palm oil in aquaculture feeds for salmonid species. European Journal of Lipid Science and Technology, 109: 394-399.

Organización de las Naciones Unidas para la Alimentación y la Agricultura (FAO). 2016. El estado mundial de la pesca y la acuicultura 2016. Contribución a la seguridad alimentaria y la nutrición para todos. Organización de las Naciones Unidas para la Alimentación y la Agricultura, Roma.

Pfaffl, M.W. 2001. A new mathematical model for relative quantification in real-time RT-PCR. Nucleic Acids Research, 29(9): e45. doi.org/10.1093/nar/29.9.e45

Peng, M., Xu, W., Mai, K.S., Zhou, H.H., Zhang, Y.J., Liufu, Z.G., Zhang, K.K. \& Ai, Q.H. 2014. Growth performance, lipid deposition and hepatic lipid metabolism related gene expression in juvenile turbot (Scophthalmus maximus L.) fed diets with various fish oil substitution levels by soybean oil. Aquaculture, 433: 442-449.

Regost, C., Arzel, J., Robin, J., Rosenlund, G. \& Kaushik, S.J. 2003. Total replacement of fish oil by soybean or linseed oil with a return to fish oil in turbot (Psetta maxima): 1. Growth performance, flesh fatty acid profile, and lipid metabolism. Aquaculture, 217(1-4): 465-482.

Rojas, C.P. \& Mendoza, R. 2000. El cultivo de especies nativas en México. Estado de Salud en la Acuacultura. Secretaría de Medio Ambiente y Recursos Naturales, Instituto Nacional de Pesca, Dirección General de Investigación en Acuacultura, México D.F., pp. 445490.

SAGARPA-INAPESCA. 2014. Carta Nacional acuícola. Secretaría de Agricultura, Ganadería y Desarrollo Rural, Pesca y Alimentación. Instituto Nacional de Pesca. [https://www.gob.mx/ conapesca/documentos/ anuario-estadistico-de-acuacultura-y-pesca]. Reviewed: 20 November 2017.
Salini, M.J., Wade, N., Bourne, N., Turchini, G.M. \& Glencross, B.D. 2016. The effect of marine and nonmarine phospholipid-rich oils when fed to juvenile barramundi (Lates calcarifer). Aquaculture, 455: 125135.

Sargent, J.R., McEvoy, L.A. \& Bell, J.G. 1997. Requirements, presentation and sources of polyunsaturated fatty acids in marine fish larval feeds. Aquaculture, 155: 119-129.

Sargent, J., McEvoy, L., Estevez, A., Bell G., Bell, M., Henderson, J. \& Tocher, D.R. 1999. Lipid nutrition of marine fish during early development: current status and future directions. Aquaculture, 179(1-4): 217-229.

Sargent, J.R., Tocher, D.R. \& Bell, J.G. 2002. The lipids. In: Halver, J.E. \& Hardy, R.W. (Eds.). Fish nutrition. Elsevier Science, New York, pp. 181-257.

Shintani, T., Takahashi, N., Fushiki, T., Kotera, J. \& Sugimoto, E. 1995. Recognition system for dietary fatty acids in the rat small intestine. Bioscience, Biotechnology and Biochemistry, 59: 1428-1432.

Taylor, J.F., Martinez-Rubio, L., Del Pozo, J., Walton, J.M., Tinch, A.E., Migaud, H. \& Tocher, D.R. 2015. Influence of dietary phospholipid on early development and performance of Atlantic salmon (Salmo salar). Aquaculture, 448: 262-272. https://doi.org/ 10.1016/j.aquaculture.2015.06.012.

Tacon, A.G.J. \& Metian, M. 2008. Global overview on the use of fish meal and fish oil in industrially compounded aquafeeds: trends and future prospects. Aquaculture, 285: 146-158.

Tacon, A.G.J. \& Metian, M. 2013. Fish matters: importance of aquatic foods in human nutrition and global food supply. Reviews in Fisheries Science, 21(1): 22-38.

Tocher, D.R., Bendiksen, E.Å., Campbell, P.J. \& Bell, J.G. 2008. The role of phospholipids in nutrition and metabolism of teleost fish. Aquaculture, 280: 21-34. doi.org/10.1016/j.aquaculture.2008.04.034

Turchini, G.M., Torstensen, B.E. \& Ng, W.K. 2009. Fish oil replacement in finfish nutrition. Reviews in Aquaculture, 1(1): 10-57.

Trushenski, J.T., Schwarz, M., Lewis, H., Laporte, J., Delbos, B., Takeuchi, R. \& Sampaio, L.A. 2011. Effect of replacing dietary fish oil with soybean oil on production performance and fillet lipid and fatty acid composition of juvenile cobia Rachycentron canadum. Aquaculture Nutrition, 17: 437-447.

Ueberschar, B. 1995. The use of tryptic enzyme activity measurement as a nutritional condition index: laboratory calibration data and field application. ICES Marine Science Symposia, 201: 119-29. 
Versaw, W., Cuppett, S.L., Winters, D.D. \& Williams, L.E. 1989. An improved colorimetric assay for bacterial lipase in nonfat dry milk. Journal of Food Science, 54: 232-254.

Walter, H.E. 1984. Proteinases: methods with hemoglobin, casein, and azocoll as substrates. In: Bergmeyern, H.U. (Ed.). Methods of enzymatic analysis. Volume V. Wiley-VCH, Weinheim, pp. 270277.

Received: 3 January 2018; Accepted: 1 March 2019
Zuo, R., Mai, K., Xu, W., Turchini, G.M. \& Ai, Q. 2015. Dietary ALA, but not LNA, increase growth, reduce inflammatory processes, and increase antioxidant capacity in the marine finfish Larimichthys crocea. Lipids, 50(2): 149-163. 